\title{
Importance of Clinical and Morphological Correlations in Diagnosing Langerhans Cell Histiocytosis
}

\author{
OMAYMA SEB ${ }^{1}$, FAUZANA K², AISYAH MR ${ }^{3}$, NORAIDAH M ${ }^{1}$, \\ NOOR HAMIDAH $\mathrm{H}^{1}$ \\ 'Department of Pathology, Faculty of Medicine, Universiti Kebangsaan Malaysia Medical \\ Centre, Jalan Yaacob Latif, Bandar Tun Razak, 56000 Cheras, Kuala Lumpur, Malaysia. \\ ${ }^{2}$ Department of Pathology, ${ }^{3}$ Department of Pediatric, Hospital Raja Permaisuri Bainun, \\ Jalan Raja Ashman, 30990 Ipoh, Perak, Malaysia.
}

\begin{abstract}
ABSTRAK
Histiositosis sel Langerhans (LCH) adalah gangguan histiositik klonal. Pelbagai manifestasi klinikal, dari lesi tulang terisolasi kepada penyakit multisistem, boleh menyebabkan kesukaran dan kelewatan pada penentuan diagnosis. Kami melaporkan pesakit kanak-kanak perempuan berumur 2 tahun 8 bulan yang mengalami demam berterusan dan kekurangan berat badan selama 2 minggu berserta distensi abdomen. Pemeriksaan fizikal menunjukkan pesakit kelihatan pucat, menghadapi proptosis bilateral, dermatitis 'seaborrheic' pada kulit kepala dan hepatosplenomegali. Pemeriksaan X-ray tengkorak menunjukkan beberapa lesi litik pada dasar dan kubah tengkorak. Morfologi sumsum tulang menunjukkan banyak sel Langerhans (LCS) dan makrofaj 'foamy' yang abnormal. Pewarnaan imunohistokimia (IHC) CD1a, S-100 and CD68 padabiopsi trefin, tidakmenunjukkan sebarang kesimpulan yang nyata. Diagnosis histiositosis multisistem sel Langerhans (MS-LCH)' pada pesakit ini telah berdasarkan pada manifestasi klinikal, analisis radiologi dan morfologi. Pesakit telah menerima rawatan kemoterapi dan pada masa kini menjalani rawatan kemoterapi 'maintenance' dengan memperolehi respons klinikal yang baik. LCH adalah penyakit yang jarang dan walaupun keputusan IHC tidak menunjukkan sebarang kesimpulan yang nyata, korelasi klinikal, radiologi dan morfologi amat penting bagi penentuan diagnosis.
\end{abstract}

Kata kunci: Histiositosis sel Langerhans, imunohistokimia, patologi

Address for correspondence and reprint requests: Noor Hamidah Hussin. Department of Pathology, Faculty of Medicine, Universiti Kebangsaan Malaysia Medical Centre, Jalan Yaacob Latif, Bandar Tun Razak, 56000 Cheras, Kuala Lumpur, Malaysia. Tel: +603-91455339 E-mail: hamidah@ppukm.ukm.edu.my 


\section{ABSTRACT}

Langerhans cell histiocytosis $(\mathrm{LCH})$ is a clonal histiocytic disorder. The variable clinical manifestations from isolated bone lesion to multisystem disease can cause difficulties and delay in diagnosis. We report a 2 years and 8 months-old girl who presented with a 2 weeks history of persistent fever and weight loss associated with progressive abdominal distension. Physical examination revealed pallor, bilateral proptosis, seaborrheic dermatitis over the scalp and hepatosplenomegaly. Skull X-ray demonstrated multiple lytic lesions at the base and the skull vault. Bone marrow morphology showed numerous abnormal Langerhans cells (LCs) and foamy macrophages. The trephine immunohistochemistry (IHC) stains for CD1a, S-100 and CD68 were inconclusive. The diagnosis of multisystem Langerhans cell histiocytosis (MS-LCH) in this patient was based on the clinical presentation, radiological and morphological analysis. She subsequently received chemotherapy and currently she is on maintenance therapy with a good clinical response. $\mathrm{LCH}$ is a rare disease and although the IHC was inconclusive, the correlation of clinical, radiological and morphological data are essential for the diagnosis.

Keywords: immunohistochemistry, Langerhans cell histiocytosis, pathology

\section{INTRODUCTION}

Langerhans cells (LCs) is bone marrow derived dendritic cells in the skin and lymph nodes (Coleman et al. 2013) and act as antigen presenting cells (Rizzo et al. 2014). Langerhans cell histiocytosis $(\mathrm{LCH})$ is a clonal disorder where pathologic Langerhans cells (LCs) have similar characteristics to bone marrow-derived Langerhans cells admixed with an inflammatory background of T-cells, macrophages, and eosinophils (Shea \& Boos 2017).

$\mathrm{LCH}$ predominantly affects children with an estimated incidence of 5 cases per million population children (Allen et al. 2015), and more commonly in males (Shea \& Boos 2017). The clinical presentation of $\mathrm{LCH}$ varies from a single-system to a multisystem life-threatening disease (Allen et al.
2015). Skeleton is the most frequently involved in a single-system disease, which accounts for $80 \%$ of the cases (Haupt et al. 2013) and primarily affects the skull (Coleman et al. 2013). Lymph nodes, skin, lung and central nervous system (CNS) are less commonly involved (Swerdlow et al. 2008). Single infiltration site commonly presents as soft tissue swelling, skin rash or enlarge lymph nodes (Swerdlow et al. 2008) and with multisystem involvement cytopenias, skin, bone lesions and hepatosplenomegaly can occur (Swerdlow et al. 2008).

The diagnosis of $\mathrm{LCH}$ should always be made with a complete clinical, histological and immunological examination of the case to prevent a misdiagnosis, particularly in reactive conditions involving regional lymph nodes (Haupt et al. 2013). LCs are 
demonstrated by the CD1a and/or Langerin (CD207) immunostaining or presence of Birbeck granules (Swerdlow et al. 2008). Other modalities used in the diagnosis include plain radiography, computed tomography (CT), and magnetic resonance imaging (MRI). $M R I$ is considered the gold standard for identification and monitoring of bony LCH (Coleman et al. 2013).

$\mathrm{LCH}$ is stratified as single system disease (SS-LCH) and multisystem disease (MS-LCH) where the distinction is based on the extent of involvement at diagnosis (Minkov et al. 2009). Patients with MS-LCH are subdivided into a 'low-risk' group and a 'risk' group (Abla et al. 2010). 'Risk' patients have at least one or more risk organs involvement such as liver, lungs, spleen or haematopoietic system and the 'low-risk' are characterized by the absence the 'risk' organ involvement (Abla et al. 2010).

We report a case where the clinical, radiological and morphological data correlation was suggestive of $\mathrm{LCH}$, although the $\mathrm{IHC}$ was not supported.

\section{CASE REPORT}

A 2 years and 8 months-old girl presented with persistent fever for 2 weeks, associated with progressive abdominal enlargement, diarrhea, loss of appetite and weight $(2-3 \mathrm{~kg})$. She had scalp lesions suggestive of seborrheic dermatitis 3 months prior to the presentation, which showed some improvement with treatment. She was delivered at full-term gestation with a birth weight of $3 \mathrm{~kg}$. Physical examination revealed pallor with bilateral proptosis. There was moderate hepatomegaly and splenomegaly (of $5 \mathrm{~cm}$ and $4 \mathrm{~cm}$, respectively), but no lymphadenopathy. The skin was generally dry and scaly with patchy seborrheic dermatitis over the scalp which was very soft and boggy on palpation. Neurologic and other system examinations were normal.

Her full blood film showed leucoerythroblastosis with hypochromic microcytic anaemia (haemoglobin $8.9 \mathrm{~g} / \mathrm{dl}$, MCV $67.3 \mathrm{fl}$, MCH 20.7 pg.), leukocytosis (WBC $13.5 \times 109 / \mathrm{L})$ and thrombocytosis (579 $x 10^{9} / \mathrm{L}$ ). Liver profile showed normal enzyme levels but reduced total protein $(54 \mathrm{~g} / \mathrm{L})$ and albumin $(25 \mathrm{~g} / \mathrm{L})$. Lactate dehydrogenase was increased (250U/L). Serum glucose and renal profile were normal. The skull X-ray showed multiple lytic lesions at the base and the skull vault, suggestive of LCH. CT-scan of the brain, neck, thorax, abdomen and pelvis demonstrated bulky lacrimal glands, hepatosplenomegaly and multiple oval-shaped soft tissues in the abdomen suspicious of lymphadenopathy. There were no intracranial lesions.

A strong clinical possibility for $\mathrm{LCH}$ was raised and a bone marrow examination was performed, which showed numerous abnormal LCs together with foamy macrophages and increased in granulopoiesis. Morphologically, the LCs were large, pleomorphic with abundant weakly basophilic cytoplasm. The nuclei were oval; some showed grooving and folding with delicately clumped chromatin and inconspicuous nucleoli (Figure 1 A \& B). The foamy macrophages were 

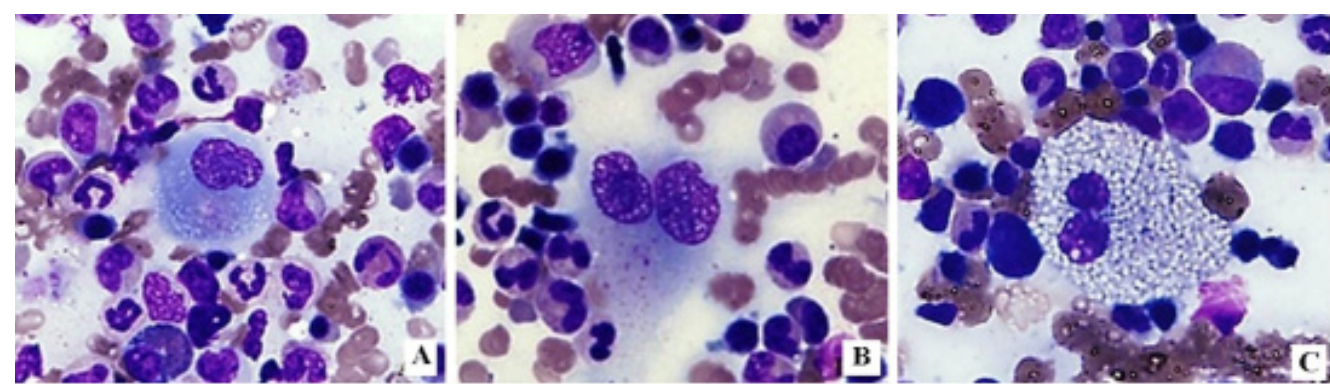

Figure 1: Bone marrow aspirate showing abnormal histiocytes (A \& B) May-GrunwaldGiemsa (MGG) x 600, and foamy macrophage (C) MGG x 400.

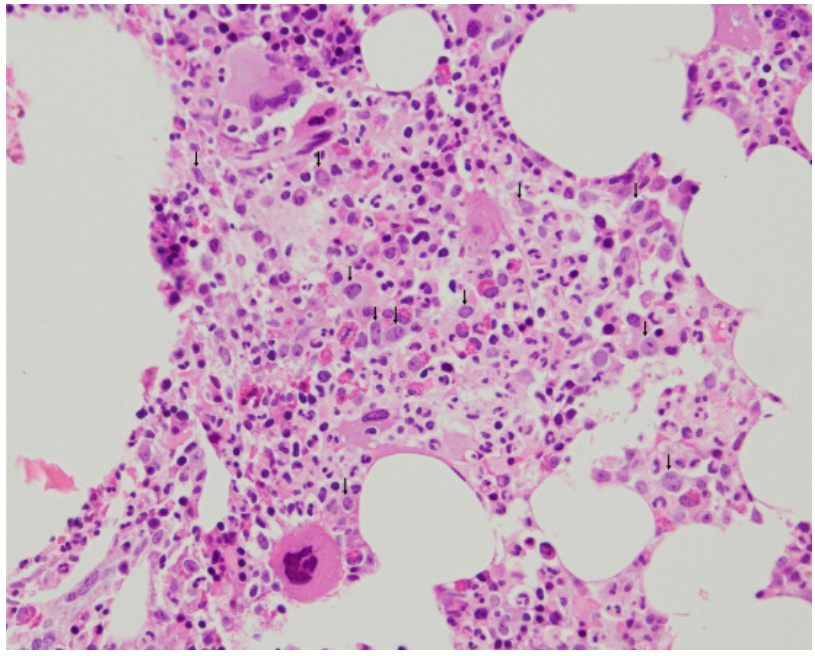

Figure 2: Bone marrow trephine showing infiltration by abnormal histiocytes Haematoxylin and Eosin (H\&E) x 400.

large with round nuclei and abundant cytoplasm, some showed binuclearity and multinuclearity (Figure 1C). These findings were highly suggestive of histiocytic neoplasm most likely LCH. Furthermore, trephine biopsy (H\&E stain) showed infiltration by clusters of large abnormal histiocytes displaying large round to oval nuclei, prominent nucleoli and moderate amount of cytoplasm (Figure 2). However, trephine immunohistochemistry showed that CD1a was weak generally and strong positivity were only in a few focal areas while S-100 and CD68 were positive only in an area but negative in others. The diagnosis was concluded as histiocytic neoplasm with a possibility of $\mathrm{LCH}$.

The patient was diagnosed as MS$\mathrm{LCH}$ involving the skull, eyes, skin, liver, spleen and bone marrow based on the clinical presentation and investigations. Upon diagnosis, she was treated, according to Histiocyte Society Treatment Guidelines 2009, with induction therapy of intravenous vinblastine and oral prednisone. She received a second induction as the disease assessment at the sixth week 
showed partial clinical response. This was followed by maintenance therapy, with pulses of prednisolone and vinblastine every 3 weeks and continuous oral 6-mercaptopurine for a total of 1-year duration to achieve a good response and remission. After 7 months of maintenance therapy, there was good clinical response with shrinkage of the liver and spleen sizes, her scalp was firm and the seborrheic dermatitis and skin lesions resolved, although there was still proptosis. There was no evidence of diabetes insipidus (DI). The patient is still undergoing treatment.

\section{DISCUSSION}

$\mathrm{LCH}$ is considered a neoplasm arising from the histiocytes or dendritic cells, with uncertainty whether it is malignant or an inflammatory nature (Haupt et al. 2013). The identification of BRAF-V600E mutations in over $50 \%$ of $\mathrm{LCH}$ lesions makes a breakthrough in understanding the pathogenesis of LCH (Allen et al. 2015). BRAF-V600E was found in many malignancies and in the hematopoietic cells in bone marrow of patients with high-risk LCH (Allen et al. 2015). These findings have led to the conclusion that $\mathrm{LCH}$ is a neoplastic disorder (Allen et al. 2015).

Morphologically, LCH is characterised by the presence of pathologic LCs admixed with a rich inflammatory background of eosinophils, monocytes, multinucleated giant cells, T-cells and plasma cells (Shea \& Boos 2017). The pathologic LCs are oval in shape, about 10-15 $\mathrm{m}$ in diameter, recognized by their grooved, folded, indented or lobulated nuclei with fine chromatin, inconspicuous nucleoli and weakly basophilic cytoplasm (Swerdlow et al. 2008). Flowcytometry analysis requires fresh tissue for analysis and there are few antibodies available for flow cytometric characterization of dendritic cells (Jaffe 1988). As the disease is often unsuspected, it posed difficulties for flowcytometry analysis (Jaffe 1988). On IHC, LCs typically express CD1a, Langerin (CD207) and S-100. In addition, the cells are positive for CD68, CD14, CD4 and vimentin (Swerdlow et al. 2008). Langerin, is a novel mannose-specific lectin specific to the cell surface and cytoplasm of LCs (Abla et al. 2010), the expression of which confirms the presence of Birbeck granules (BG) (Swerdlow et al. 2008). Electron microscopy (EM) can be used to identify BG but with the availability of IHC staining, EM is no longer necessary (Minkov et al. 2009). The number of LCs with identifiable BG can also vary depending on the lesional tissue specimen type, such as from the liver, spleen, gastrointestinal tract and CNS (Minkov et al. 2009).

The Histiocyte Society Writing group classified the criteria for the diagnosis of $\mathrm{LCH}$ to presumptive, designated and definitive (Favara et al. 1997). Presumptive diagnosis is based on the characteristic morphologic features of LCH cells by light microscopy (Favara et al. 1997). Designated diagnosis requires the light morphologic features and positivity of two or more $\mathrm{IHC}$ for adenosine triphosphatase, S-100 protein, alpha-D-mannosidase or peanut lectin, whereas, definitive 
diagnosis can only be confirmed by the presence of BG on EM or by demonstration of CD1a and/or CD207 on IHC (Favara et al. 1997). However, more recent studies have identified positivity of both CD207 and CD1a in a subset of cells that reside in the cortical thymocytes, dermis and lymphoid tissue, thus excluding their use as unique markers of LCs (Minkov et al. 2009). In the appropriate clinical setting however, these markers can be useful for the diagnosis of LCH (Abla et al. 2010).

In this case of MS-LCH with risk organ involvement, the clinical presentation and imaging study were highly suggestive of $\mathrm{LCH}$. The bone marrow examination findings support the diagnosis of $\mathrm{LCH}$ although $\mathrm{IHC}$ staining was inconclusive due to technical difficulties related to the preanalytical suboptimal conditions.

As a result of disease heterogeneity, no current universally accepted LCH treatment guidelines are available (Rizzo et al. 2014). Treatment options mainly depend on the extent and severity of disease at diagnosis (Abla et al. 2010). For patients who have localized bone lesions, treatment includes curettage and/or corticosteroid injection (Allen et al. 2015). Large pelvic or vertebral lesions may be treated with systemic therapy or radiation therapy (Allen et al. 2015). A combination of prednisone and vinblastine for 6 weeks is considered the standard induction therapy for all patients with systemic disease and has proven to be effective treatment with minimal toxicity. Assessment of the disease is necessary at the end of the initial therapy (Minkov et al. 2009). Failure to respond within 6 weeks is associated with a high risk of treatment failure and a different therapy may be required. A second course of vinblastine and prednisone is recommended in patients who have shown good response but with some active disease. Patients who achieved complete remission after 6-12 weeks of induction therapy are recommended to continue with maintenance therapy with vinblastine and prednisone every 3 weeks and daily 6-mercaptopurine for a total duration of 12 months (Minkov et al. 2009).

Most of patients with SS-LCH have an excellent prognosis with spontaneous remission (Abla et al. 2010). Patients with MS-LCH at diagnosis may have variable clinical course (Minkov et al. 2009).

A higher chance of long-term survival is seen in patients with lowrisk and patients with involvement of risk organs that responded to standard induction therapy (Minkov et al. 2009). Patient's response to the induction therapy is considered the single best prognostic indicator, with a survival rate of up to $91 \%$ in those who respond (Satter \& High 2008). Other prognostic factors include age at presentation, where children less than two years old, multisystem involvement and end organ dysfunction have a worse outcome (Coleman et al. 2013).

Long-term complications have been reported in at least $71 \%$ of multisystem disease survivors despite adequate treatment (Satter \& High 2008) with $66 \%$ mortality for young Children with multisystem involvement who 
do not respond to therapy (Swerdlow et al. 2008). Diabetes insipidus is the most common complication (40\%) and other endocrinopathies; as well as parenchymal brain disease (Minkov et al. 2009). Second malignancies, particularly solid tumors and haematological malignancies are also seen (Satter \& High 2008).

\section{CONCLUSION}

We diagnosed a child with MS$\mathrm{LCH}$ in whom the correlation of clinical presentation, radiological and histology findings were pivotal in the diagnosis.

\section{REFERENCES}

Abla, O., Egeler, R.M., Weitzman, S. 2010. Langerhans cell histiocytosis: current concepts and treatments. Cancer Treat Rev 36(4): 354-9.

Allen, C.E., Ladisch, S., McClain, K.L. 2015. How I treat langerhans cell histiocytosis. Blood 126(1): 26-35.

Coleman, M.A., Matsumoto, J., Carr, C.M., Eckel, L.J., Nageswara Rao, A.A. 2013. Bilateral temporal bone langerhans cell histiocytosis: radiologic pearls. Open Neuroimag J 7: 53-7.

Favara, B.E., Feller, A.C., Pauli, M., Jaffe, E.S., Weiss, L.M., Arico, M., Bucsky, P., Egeler, R.M., Elinder, G., Gadner, H., Gresik, M., Henter, J.I., Imashuku, S., Janka-Schaub, G., Jaffe, R., Ladisch, S., Nezelof, C., Pritchard, J. 1997. Contemporary classification of histiocytic disorders. The WHO Committee on Histiocytic/ Reticulum Cell Proliferations. Reclassification Working Group of the Histiocyte Society. Med Pediatr Oncol 29(3): 157-66.

Haupt, R., Minkov, M., Astigarraga, I., Schafer, E., Nanduri, V., Jubran, R., Egeler, R.M., Janka, G., Micic, D., Rodriguez-Galindo, C., Van Gool, S., Visser, J., Weitzman, S., Donadieu, J. 2013. Langerhans cell histiocytosis $(\mathrm{LCH})$ : guidelines for diagnosis, clinical work-up, and treatment for patients till the age of 18 years. Pediatr Blood Cancer 60(2): 175-84.

Jaffe, E.S. 1988. Histiocytoses of lymph nodes: biology and differential diagnosis. Semin Diagn Pathol 5(4): 376-90.
Minkov, M., Grois, N., Mcclain, K., Nanduri, V., Rodriguez-Galindo, C., Simonitsch-Klupp, I., Visser, J., Weitzman, S., Whitlock, J., Windebank, K. 2009. Windebank- Langerhans Cell Histiocytosis: Histiocyte Society Evaluation and Treatment Guidelines. https:// histiocytesociety.org/document.doc?id=290. Last accessed on April 2009.

Rizzo, F.M., Cives, M., Simone, V., Silvestris, F. 2014. New Insights into the molecular pathogenesis of langerhans cell histiocytosis. Oncologist 19(2): 151-63.

Satter, E.K., High, W.A. 2008. Langerhans cell histiocytosis: a case report and summary of the current recommendations of the Histiocyte Society. Dermatol Online J 14(3): 3.

Shea, C.R., Boos, M.D. 2017. Langerhans Cell Histiocytosis [MedScape Web site] http:// emedicine.medscape.com/article/1100579. Last accessed on 7.3.2017.

Swerdlow, S.H., Campo, E., Harris, N.L., Jaffe, E.S., Pileri, S.A., Stein, H., Thiele, J., Vardiman, J.W. 2008. Who Classification of Tumors of the Hematopoietic and Lymphoid Tissue. Lyon: IARC. Website: http://apps.who.int/bookorders/ anglais/detart1.jsp?codlan $=1 \&$ codcol $=70 \&$ codc $\mathrm{ch}=4002$. Last accessed on 14.5.2017

Received: 16 May 2017

Accepted: 23 Oct 2017 